\title{
CHARACTERIZATION OF EFFLUENT FROM TANNERY INDUSTRY IN WARANGAL
}

\author{
D. Seshi Kala, Vinugala Pavan Kumar and Ashok Gellu \\ Department of Environmental Science, Osmania University, Hyderabad, India \\ Email: dr.shashidsk@gmail.com
}

\begin{abstract}
Physicochemical parameters of ground water (inside the industrial premises) and untreated effluent, such as $P^{H}$, Turbidity, Total Solids, Total Suspended Solids, Total Dissolved Solids, BOD, COD, Chromium (VI) were analysed by following ISO pocedures and expressed in $\mathrm{mg} / \mathrm{L}$ except $P^{H}$. This was repeated for every alternate month for 1 year. TDS $(192.6+63.1$ to $410.6 \pm 18.4)$; COD (256 \pm 274 to $410.6 \pm 50.8 \mathrm{mg} / \mathrm{L})$; Total hardness (83.3 \pm 11.9 to 164.3 $\pm 5.1 \mathrm{mg} / \mathrm{L})$. Chromium (VI) $(0.1 \pm 0$ to $0.2 \pm 0.1)$ were recorded in groundwater. The Untreated tannery effluent has following ranges in respective parameters $B O D(5100 \pm 173.2$ to $6933.3 \pm 519.6) ; C O D(15960 \pm 173.2$ to $19000 \pm 222.7)$, sulfides $(148 \pm 34.6$ to $201 \pm 24.3)$. Chromium (VI) (142.5 \pm 24.5 to $239 \pm 33.4)$ was above the permissible limits (BIS Inland Discharge Standards).
\end{abstract}

Key words: Tanning Industry, Tannery effluents, Biological Oxygen Demand (BOD), Chemical Oxygen Demand (COD), Total Dissolved Solids (TDS), Total Solids (TS).

\section{Introduction}

The tanning industry is typically portrayed as one of the pollutions producing businesses that turnout wide varieties of high loads of pollutants. The tanning procedure is a wet procedure that spends more quantities of water and produces about $90 \%$ of the spent water as effluent (Chowdhury et al. 2013). It's perceived a huge ecological danger because of large amounts of pollutants like salinity, organic, inorganic burden, dissolved, suspended solids, specific contaminations (sulfide, chromium, chloride, and other salt deposits) and critical heavy metals and so on. (Cooman et al. 2003; Boshoff et al. 2004; Chaudry et al. 1997; Tariq et al. 2005; Apte et al. 2005; Leghouichi et al. 2009; Akan et al. 2007). From the total water consumed in the tanning process water $90 \%$ of the water is discharged as effluent. Apart from the making of leather, strong liquid and vaporous wastes are additionally released. In the chrome tanning process, $40 \%$ unused chromium salts are generally released in the final effluents, making a genuine danger to nature (Leghouichi et al. 2009; Owlad et al. 2008; Greenstein et al. 2005). Exposure to chromium, pentachlorophenol and another dangerous toxin increment the danger of dermatitis, ulcer, perforation of nasal septum and lung disease (Carlos et al. 2002) Chromium is known to be exceptionally harmful to the aquatic organisms in the hexavalent form than the trivalent form. Hexavalent chromium is carcinogenic and mutagenic, even with a little amount $(10 \mathrm{mg} / \mathrm{L})$ can cause nausea, vomiting, skin irritation and problems related to the respiratory tract which can cause lung carcinoma due to chromium toxicity (Subramani et al. 2002). With no exemptions there is no cost effective effluents treatment plant (ETP) in leather the tanning industries, the tannery industry is in transition about human wellbeing and ecological security. The tannery emanating decimates the life of accepting water bodies and land surface (Cooman et al. 2003)

There are around 2161 tanneries that procedure 500,000 a lot of stows away and 314 kilograms of skins every year. This industry is widely unfurled in Tamilnadu, Kanpur, Karnataka and Rajasthan (Vijayanand and Hemapriya, 2014). In Tamilnadu alone, there are around 1120 tanneries set in Vellore, Ranipet, Trichy, Dindugal, Erode and Pallavaram in the urban focus (Noorjahan, 2014). In India chromium is discharged into the environment from tanneries in the range of 2000 to $5000 \mathrm{mg} / \mathrm{L}$ in contrast to the prescribed discharge limits of $2 \mathrm{mg} / \mathrm{L}$ (Altaf et al., 2008). Tanneries have been present in Warangal since 1830 when the Nizam ruled the area. The hide was treated in a crude manner using herbs. In 1965, chemicals were introduced to clean the hides. Because of many reasons, the number of tanneries has descended throughout 
the years and the old magnificence is lost until the end of time. Presently, just twelve tanneries exist in Desaipet and Enumamula territories in Warangal town employing around 100 workers each on an average (The Hindu Jan 2013). This was during 2013 and now there is just a single industry left barely battling for the existence. The present study aims to provide an effective, ecofriendly treatment technique specifically to the tannery industry, for which characterization of the effluent is mandatory to formulate the treatment technique. As a part of this, the samples were collected at regular intervals of the time from the industry.

\section{Study Area}

The study area is located at Warangal, Desipet road, near Enumamula grain market and the coordinates of the industry are $18.0000152 \mathrm{~N} ; 79.6235566 \mathrm{E}$.

\section{Materials and Methods}

Collection of samples: The common effluent was collected freshly from the outlet (comes collectively from all process of the industry) and it was stored in a pre-sterilized, brown bottle. For the estimation of BOD, $300 \mathrm{ml}$ BOD bottles also carried to the sample collection site, at the time of sampling, dissolved oxygen is fixed by adding Mn (II) under basic conditions. The samples were taken to the lab as early as possible and it was protected from sunlight during transportation. The samples were preserved using a refrigerator. Then the samples were subjected to the analysis. This study was conducted in the year 2018-19, for every alternative month (January, March, May, July, September, November) samples were collected, analyzed with the instrument/ method used for analysis are represented in Table 1. At every collection, 3 samples were collected and analyzed and represented in Tables 2 - 5 with mean and standard deviation values. In this study physical parameters such as $\mathrm{pH}$, Turbidity, Total Solids, TDS, TSS and Chemical parameters such as BOD, COD, Chlorides, Sulfides, and Chromium (VI) are analyzed by following standard procedures.

Table 01: Estimation of physio-chemical parameters

\begin{tabular}{|l|l|c|l|}
\hline$\#$ & Name of the experiment & Instrument/ method used for analysis & Test method \\
\hline 1 & Estimation of $\mathrm{pH}$ & $\mathrm{pH}$ meter & IS-3025- Part 11 \\
\hline 2 & Estimation of Turbidity & Turbidimeter & IS-3025- Part 10 \\
\hline 3 & Estimation of Total Solids & Simple balance & - \\
\hline 4 & Estimation of TDS & TDS meter & IS-3025- Part 16 \\
\hline 5 & Estimation of TSS & Weighting & - \\
\hline 6 & Estimation of BOD & Titrimetric & IS-3025- Part 44 \\
\hline 7 & Estimation of COD & Titrimetric & IS-3025- Part 58 \\
\hline 8 & Estimation of Chloride & Titrimetric & IS-3025- Part 32 \\
\hline 9 & Estimation of Sulphide & UV-Visible & IS-3025- Part 29 \\
\hline 10 & Estimation of Chromium & Spectrophotometer & IS-3025- Part 52 \\
\hline
\end{tabular}

Table 02: Analysis of physical parameters of Groundwater

\begin{tabular}{|l|l|l|l|}
\hline Parameter & $\mathbf{P}^{\mathbf{H}}$ & Turbidity & TDS \\
\hline January & $6.76 \pm 0.3$ & $14.6 \pm 5.5$ & $345 \pm 21.7$ \\
\hline March & $7 \pm 0.2$ & $15 \pm 2$ & $241.6 \pm 14.4$ \\
\hline May & $6.67 \pm 0.3$ & $13.3 \pm 5.5$ & $192.6 \pm 63.1$ \\
\hline July & $6.5 \pm 0.25$ & $12.3 \pm 4.5$ & $465 \pm 31.2$ \\
\hline September & $6.67 \pm 0.41$ & $21.3 \pm 3.2$ & $387 \pm 81.2$ \\
\hline November & $7.06 \pm 0.2$ & $21 \pm 5.3$ & $410.6 \pm 18.4$ \\
\hline BIS Drinking Water Standards & $6.5-8.5$ & 10 & 500 \\
\hline
\end{tabular}

${ }^{*}$ All the values are expressed in $\mathrm{mg} / \mathrm{L}$ except $\mathrm{pH}$ and turbidity. 
Table 03: Analysis of Chemical parameters of Groundwater

\begin{tabular}{|l|c|c|c|c|}
\hline \multicolumn{1}{|c|}{ Parameter } & BOD & COD & Total Hardness & Chromium (VI) \\
\hline January & $30 \pm 8.6$ & $410.6 \pm 50.8$ & $117.6 \pm 8.3$ & $0.2 \pm 0$ \\
\hline March & $28 \pm 7$ & $328 \pm 13.9$ & $100 \pm 13.2$ & $0.2 \pm 0.1$ \\
\hline May & $16 \pm 1.7$ & $256 \pm 27$ & $83.3 \pm 11.9$ & $0.1 \pm 0$ \\
\hline September & $37 \pm 6.2$ & $408 \pm 16$ & $157.6 \pm 10.7$ & $0.2 \pm 0$ \\
\hline November & $32 \pm 3.4$ & $357.3 \pm 16$ & $137 \pm 2.5$ & $0.1 \pm 0$ \\
\hline $\begin{array}{l}\text { BIS Drinking Water } \\
\text { Standards }\end{array}$ & 30 & - & 300 & 0.05 \\
\hline
\end{tabular}

${ }^{*}$ All the values are expressed in $\mathrm{mg} / \mathrm{L}$.

Table 04: Physical Characteristics of Untreated Effluent

\begin{tabular}{|l|l|l|l|l|l|}
\hline Parameter & $\mathbf{P}^{\mathrm{H}}$ & TSS & TS & TDS & Turbidity \\
\hline January & $4.9 \pm 0$ & $17573.3 \pm 2019.2$ & $25200 \pm 2151.74$ & $7626.6 \pm 210.7$ & $278.3 \pm 70$ \\
\hline March & $5 \pm 0.2$ & $13360 \pm 2150$ & $18710 \pm 2264.5$ & $5350 \pm 173.4$ & $248.3 \pm 20.5$ \\
\hline May & $4.6 \pm 0$ & $9113 \pm 974.9$ & $13566.7 \pm 1101.5$ & $4453.3 \pm 1361$ & $230 \pm 22.9$ \\
\hline July & $6.24 \pm 0.6$ & $22587 \pm 610.5$ & $29666.7 \pm 404.1$ & $7079.6 \pm 216.7$ & $278 \pm 20.6$ \\
\hline September & $6.27 \pm 0.25$ & $18760 \pm 2020.5$ & $27100 \pm 1802.7$ & $8340 \pm 269.6$ & $293.6 \pm 6.5$ \\
\hline November & $6.3 \pm 0.4$ & $18490 \pm 2259$ & $27223.3 \pm 2289.8$ & $8743 \pm 81.4$ & $323.3 \pm 25.1$ \\
\hline $\begin{array}{l}\text { BIS } \\
\text { Discharge } \\
\text { Standard }\end{array}$ & 5.5 to 9.0 & 100 & - & 2000 & 10 \\
\hline
\end{tabular}

${ }^{*}$ All the values are expressed in $\mathrm{mg} / \mathrm{L}$ except $\mathrm{pH}$ and turbidity.

Table 05: Chemical Characteristics of Untreated Effluent

\begin{tabular}{|l|l|l|l|l|l|}
\hline Parameter & BOD & COD & Chloride & Sulphide & Chromium (VI) \\
\hline January & $5100 \pm 173.2$ & $15960 \pm 40$ & $2885 \pm 188.6$ & $148 \pm 34.6$ & $239 \pm 33.4$ \\
\hline March & $5333.3 \pm 378.5$ & $15493.3 \pm 61.1$ & $2637 \pm 27.9$ & $120.6 \pm 11.1$ & $167 \pm 11.7$ \\
\hline May & $5066.6 \pm 378.5$ & $16353.3 \pm 450$ & $2785.5 \pm 14.7$ & $120 \pm 12.6$ & $159.5 \pm 17.7$ \\
\hline July & $6300 \pm 360.5$ & $18533.3 \pm 611$ & $3015.1 \pm 96.3$ & $129.4 \pm 4.8$ & $192 \pm 5$ \\
\hline September & $6266.6 \pm 461.8$ & $19000 \pm 222.7$ & $3183.1 \pm 133.6$ & $169.6 \pm 2.7$ & $142.5 \pm 24.5$ \\
\hline November & $6933.3+519.6$ & $17440 \pm 41.5$ & $3405.6 \pm 119.7$ & $201 \pm 24.3$ & $187.7 \pm 12.4$ \\
\hline $\begin{array}{l}\text { BIS } \\
\text { Discharge } \\
\text { Standard }\end{array}$ & 30 & 250 & 1000 & 2 & 1 \\
\hline All & & \multicolumn{3}{|l}{} \\
\hline
\end{tabular}

${ }^{*}$ All the values are expressed in $\mathrm{mg} / \mathrm{L}$.

\section{Results and Discussion}

Groundwater: Before the conducting study of the tannery effluent characterization groundwater was analyzed because the industry was oldest, and it was running successfully without any effective effluent treatment. From tables $2 \& 3$, the following parameters are seen as follows

$\mathbf{P}^{\mathrm{H}}$ : The $\mathrm{P}^{\mathrm{H}}$ was recorded in the range of $6.5 \pm 0.25$ to $7.06 \pm 0.2$, which is in the permissible limit i.e. $6.5-8.5$

Turbidity: turbidity was recorded in the following range $13.3 \pm 5.5$ to $21 \pm 5.3$ NTU, which is above the permissible limiting i.e. 10 NTU.

Total Dissolved Solids: Total Dissolved solids of the effluents are in the range $192.6+63.1$ to $410.6 \pm 18.4 \mathrm{mg} / \mathrm{L}$, which is below the permissible limit i.e. $500 \mathrm{mg} / \mathrm{L}$.

Biological Oxygen Demand: From the table 3, it was known that the BOD value was in the range from $16 \pm 1.7 \mathrm{mg} / \mathrm{L}$ to $37 \pm 6.2 \mathrm{mg} / \mathrm{L}$. 
Chemical Oxygen Demand: COD value ranged between $256 \pm 274$ to $410.65 \pm 0.8 \mathrm{mg} / \mathrm{L}$.

Total Hardness: Total hardness was recorded in the range of $83.3 \pm 11.9$ to $164.3 \pm 5.1 \mathrm{mg} / \mathrm{L}$. which is below the permissible limit i.e., $600 \mathrm{mg} / \mathrm{L}$.

Chromium (VI): Very high concentration of hexavalent Chromium was detected in the present study $0.1 \pm 0$ to $0.2 \pm 0.1 \mathrm{mg} / \mathrm{L}$, which is above the permissible limit i.e., $0.05 \mathrm{mg} / \mathrm{L}$.

Like our study, Sivakumar 2014 conducted groundwater Quality assessment around Nagalkeni Tannery Industrial Belt, Tamilnadu, and reported that all physiochemical parameters were above permissible limits set by BIS. So, they are not at all suitable for drinking or any other purpose. When such polluted water is used for the tanning process effluent shows still higher values.

Untreated common effluent: The following physical and chemical parameters and the observations of untreated tannery effluent are represented in Tables 4 \& 5 .

$\mathbf{P}^{\mathrm{H}}$ : In the sample of January (4.9) and May (4.6) the $\mathrm{P}^{\mathrm{H}}$ of the effluent was acidic while in November it was nearer to neutral i.e. $6.3 \pm 0.4$ which is below the Inland discharge standard i.e. 5.5 to 9.0 the reason can be attributed to dilution factor. The Acidic nature of the effluents can be attributed to the irrational addition of sulphuric acid during the pickling stage. The $\mathrm{pH}$ value was recorded between $4.6 \pm 0$ to $6.3 \pm 0.4$. Rabah and Ibrahim (2010) conducted a study on physical, chemical and microbial characterization laden with tannery effluent and found that $\mathrm{P}^{\mathrm{H}}$ of the effluents was neutral. Hugo Springer (1994) conducted the characterization of tannery wastes at different stages of the tanning process and found that their $\mathrm{P}^{\mathrm{H}}$ was wide starting from 2.8 to 12.5 .

Total Solids: Total solids of the effluents are in range $25200 \pm 2151.7$ to $27223.3 \pm 2289.8$ and above the permissible limits, this was due to different the tanning processes consume different chemicals and much more organic solids are sent out the prescribed limits of the TDS is 200 $\mathrm{mg} / \mathrm{L}$ for discharging into the inland surface water. Such high quality of total solids (TDS \& TSS) would damage soil flora and fauna and Soil porosity and soil texture, water holding capacity, etc. (Chowdhury et al. 2013), (Jeyasingh and Philip L 2005). Similar to our present study Arasappan Sugasini and Kalyanaraman Rajagopal (2015) concluded that Total Solids of untreated and treated effluent were studied and found that results were exceeding than the permissible limit. This attributed to the quality of the hides and skins processed in the tannery (Islam et al., 2014). High levels of TDS are aesthetically not accepted by the society it may create distress in humans and livestock (Patel et al., 2009).

BOD and COD : From the table of Chemical parameters, it was seen that the BOD value was $5100 \pm 173.2 \mathrm{mg} / \mathrm{L}$ recorded less in January and it was maximum in November was $6933.3 \pm$ $519.6 \mathrm{mg} / \mathrm{L}$ which was above the Inland discharge standard $30 \mathrm{mg} / \mathrm{L}$. COD value ranged between $15960 \pm 173.2$ to $19000 \pm 222.7 \mathrm{mg} / \mathrm{L}$ which was above the discharge standard 250 $\mathrm{mg} / \mathrm{L}$. Values of BOD and COD agree with the earlier study by UNEP 1999; (Manjushree Chowdhury et. al 2015, Akan et. al 2007, Verma et. al 2008). The tanning process includes the addition of different inorganic and organic loads, which leads to increased BOD, COD values. When they have discharged the aquatic ecosystem, depletes the oxygen levels alters the $\mathrm{P}^{\mathrm{H}}$ and gives intense coloration to the waterbody. Dissolved oxygen below $4 \mathrm{mg} / \mathrm{L}$ in the aquatic system is not at all suitable to the aquatic life (Trivedy and Goel 1986; Alam and Malik 2008).

Chloride: Chlorides were recorded the range of $2637 \pm 27.9$ to $3405.6 \pm 119.7 \mathrm{mg} / \mathrm{L}$, the results showed exceed the levels of chlorides than the permissible limits $1000 \mathrm{mg} / \mathrm{L}$ as discharged into the inland water surface. This can be attributed to the process of soaking and pickling, were in sodium chloride salts were extensively used. Sharma and Malaviya (2013) conducted similar studies and reported all physical and chemical parameters were above the permissible limits.

Sulphides: The range of sulfide is $148 \pm 34.6$ to $201 \pm 24.3 \mathrm{mg} / \mathrm{L}$. Sulfides were recorded objectionably high than the permissible limit of $2 \mathrm{mg} / \mathrm{L}$ of the effluents discharged into inland surface water. The high concentration of sulfides was toxic to the aquatic organisms and 
maybe to the organisms employed in the biological treatment system. Sharma and Malaviya (2013) conducted similar studies and reported all physical and chemical parameters were above the permissible limits.

Chromium (VI): Sharma and Malaviya (2013) conducted similar studies and reported all physical and chemical parameters were above the permissible limits. Vidya and Usha conducted a study on wastewater and concluded that a high level of metal such as Iron, Nickel, Chromium, Zinc, Cadmium, and Manganese contaminates agricultural soil. The crops from such soil when they are consumed cause serious health issues (Mohanta et al., 2010). A Very high concentration of hexavalent Chromium was detected in the present study $142.5+24.5$ to $239 \pm 33.4 \mathrm{mg} / \mathrm{L}$ which was above the discharge standard i.e. $1 \mathrm{mg} / \mathrm{L}$. this can be attributed to the fact the tanning and retaining is done with the chromium salts only in the industry, Similar trends were observed in the different studies conducted by Deepali and Gangwar, 2010.

\section{Conclusion}

Leather industries uses a variety of tanning processes or techniques for making different leather products, most of the industry's concern is to make money ignoring the environmental concerns. Effluent treatment is investment immense system, no tanner comes forward to invest amount from their profits. Because almost of these are small scale industries. If there is support from the government to help such industry by supplying facilities about the effluent treatment this sector can improve the GDP of the country. The present study reveals that the complexity of the tannery effluent is unable to address the existing treatment technologies. This was clear from the groundwater analysis; one common effluent treatment was set up but due to some technical issues it is unable to treat the effluent. The study strongly recommends setting up a specific cost-effective eco-friendly treatment technology. The Authors are working seriously on these grounds.

\section{References}

1. Alam ZM, Malik A (2008) Chromate resistance, transport and bio-reduction by Exiguobacterium sp. ZM-2 isolated from agricultural soil irrigated with tannery effluent. $J$ Basic Microbiol 48:1-5.

2. Arasappan Sugasini and Kalyanaraman Rajagopal. Characterization of Physicochemical Parameters and heavy metal Analysis of Tannery Effluent, Department of Biotechnology, VISTAS (Vels University), Old Pallavaram, Chennai, India Int.J.Curr.Microbiol.App.Sci (2015) 4(9): 349-359.

3. Akan JC, Moses EA, Ogugbuaja VO (2007) Assessment of tannery industrial effluent from Kano metropolis, Nigeria Asian Network for Scientific Information. J Appl Sci 7(19):27882793.

4. Altaf, M.M., Masood, F., Malik, A. 2008. Impact of long-term application of treated tannery effluents on the emergence of resistance traits in Rhizobium sp. isolated from Trifolium alexandrinum. Turk. J. Biol., 32: 1-8.

5. A.D. Apte, S. Verma, V. Tare, P. Bose, Oxidation of $\mathrm{Cr}$ (III) in tannery sludge to $\mathrm{Cr}$ (VI): Field observations and theoretical assessment, Journal of Hazardous Materials B 121 (2005) 215-222.

6. Boshoff G, Duncan J, Rose PD (2004) Tannery effluent as a carbon source for biological sulphate reduction. Wat Res 38(11):2651-2658.

7. Chowdhury M, Mostafa MG, Biswas TK, Saha AK (2013) Treatment of leather industrial effluents by filtration and coagulation processes. Water Res Ind 3:11-22.

8. Cooman K, Gajardo M, Nieto J, Bornhardt C, Vidal G (2003) Tannery waste water characterization and toxicity effects on Daphnia Spp. Environ Toxicol 18:45-51.

9. D. Sivakumar. Groundwater Quality Assessment around Nagalkeni Tannery Industrial Belt. World Academy of Science, Engineering and Technology, International Journal of Civil and Environmental Engineering Vol:8, No:3, (2014) 1-6.

10. Deepali, K.K., Gangwar, 2010. Metals concentration in textile and tannery effluents, associated soils and groundwater. NY. Sci. J., 3: 82-89.

11. E. Leghouichi, E. Laib, M. Guerbet, Evaluation of chromium contamination in water, sediment and vegetation caused by the tannery of Jijel (Algeria): a case study, Environmental Monitoring and Assessment 153 (2009) 111-117. 
12. TheHindu Jan, 2013.

13. Hugo Springer, (1994). John Arthur Wilson Memorial Lecture "Treatment of Industrial Wastes of the Leather Industry - is it still a Major Problem". JALCA, 89, 153-185.

14. Islam, B.I., Musa, A.E., Ibrahim, E.H., Salma, A.A.S., Babiker, M.E. 2014. Evaluation and characterization of tannery waste water. J. Forest Prod. Ind., 3: 14-150.

15. J.W. van Groenestijn, J.S. Langerwerf, M. Lucas, Reducing environmental emissions in tanneries, Journal of Environmental Science and Health Part AToxic/Hazardous Substances and Environmental Engineering 37 (4) (2002) 737743.

16. K. Carlos, W. Katarzyna, W. Kazimierg, M.M. Juan, E. Laura, L. Nava, R.G. Gomez, Possible adverse effects of chromium in occupational exposure of tannery workers, Industrial Health 40 (2002) 207-213.

17. Manjushree Chowdhury \& M. G. Mostafa. Characterization of the Effluents from Leather Processing Industries Environ. Process. (2015) 2:173-187.

18. Mohan, D., Kunwar, P.S., Vinod, K.S. 2006. Trivalent chromium removal from waste water using low cost activated carbon derived from agricultural waste material and activated carbon fabric cloth. J. Hazard. Mater. 135: 280-295.

19. Mohanta, M.K., Salam, M.A., Saha, A.K., Hasan, A., Roy, A.K. 2010. Effect of tannery effluents on survival and histopathological changes in different organs of Channa puntatus. Asian J. Exp. Biol. Sci., 1: 294 - 302.

20.M. Owlad, M.K. Aroua, W.A.A. Daud, S. Baroutian, Removal of hexavalent chromium-contaminated water and wastewater, Water, Air, and Soil Pollution 200 (2008) 59-77.

21. Noorjahan, C.M. 2014. Physicochemical characteristics, identification of fungi and biodegradation of industrial effluent. J. Environ. Earth Sci., 4: 32-39.

22. Patel, H., Gupte, A., Gupte, S. 2009. Effect of different culture conditions and inducers on production of laccase by a basidiomycete fungal isolates Pleurotus ostreatus. Biosources, 4: 268-284.

23. Rabah, A.B., Ibrahim, M.L. 2010. Physicochemical and microbiological characterization of soils laden with tannery effluents in Sokoto, Nigeria. Nigerian J. Basic Appl. Sci., 18: 65-71.

24. Sharma, S., Malaviya, M. 2013. Bioremediation of tannery waste water by Aspergillus niger SPFSL2-a isolated from tannery sludge. Int. J. Basic Appl. Sci., 2: 88 - 93.

25. Trivedy RK, Goel PK (1986) Chemical and Biological Methods for Water Pollution Studies. Environmental Publication, Karad.

26. T. Subramani D. Haribalaji, Biodegradation of Tannery Effluent and Designing the Reactor for Clarifier and Activated Sludge Process, International Journal of Modern Engineering Research Vol.2, Issue.3, May-June 2012 pp-774-781.

27. S.R. Tariq, N. Shaheen, A. Khalique, S. Manzoor, M. Jaffar, Multivariate analysis of selected metals in tannery effluents and related soil, Journal of Hazardous Materials A 122 (2005) 17-22.

28. UNEP (1991) Tanneries and the Environment: a technical guide to reducing the environmental impact of tannery operations. United Nations Environment Programme, Industry and Environment, Programme Activity Centre (UNIDO, IE/PAC), Paris.

29. UNEP (2010). Clearing the water: A focus on water quality solutions. Nirobi, Kenya.

30. Verma T, Ramteke PW, Grag SK (2008) Quality assessment of treated tannery wastewater with special emphasis on pathogenic E. coli detection through serotyping. Environ Monit Assess 145:243-249.

31. Vidya, S., Usha, K. 2007. Remediation potential of Ocimum basilicum against tannery wastes. Pollut. Res., 26: 421-425. 